\title{
Готовність фахівців із реабілітації до використання сучасних інформаційно- комунікаційних технологій для забезпечення безперервної реабілітаційної допомоги пацієнтам із травмами
}

\author{
В.В. Брич, Н.Ю. Ходаковська \\ Державний вищий навчальний заклад «Ужгородський національний університет», Ужгород, Україна
}

\begin{abstract}
Анотація. Мета: визначити готовність і потенційні можливості використання інформаційно-комунікативних технологій фахівцями з реабілітації для забезпечення ефективної безперервної реабілітаційної допомоги пацієнтам із травмами у сучасних умовах. Об'єкт і методи дослідження. Використано методи системного підходу і системного аналізу, соціологічний та статистичний методи. У дослідженні взяли участь 62 фахівці з реабілітації. Опитування проводили дистанційно за допомогою спеціально розроблених анкет із 25 питань. Результати. 64,5+12,0\% респондентів вважають доцільним та ефективним використання сучасних інформаційно-комунікаційних технологій та телемедицини в реабілітації. 48,4 $12,5 \%$ опитаних фахівців вже готові використовувати сучасні комуні-

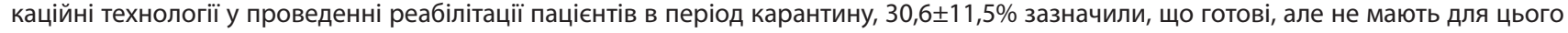
можливості, $21,0 \pm 10,2 \%$ - не готові, оскільки вважають їх неефективними. 45,2 $12,5 \%$ респондентів готові долучитися до розробки реабілітаційних онлайн-програм, їх методичного забезпечення, сайтів та сервісів сучасних інформаційних технологій для забезпечення безперервної реабілітації пацієнтів. Визначено основні перешкоди та ризики реалізації телереабілітації, на погляд опитаних фахівців із реабілітації. Висновки. Визначено високий рівень $(79,0 \%)$ готовності фахівців із реабілітації до використання сучасних інформаційно-комунікаційних технологій у реабілітації пацієнтів із травмами у своїй практиці та середній рівень (45,2\%) готовності долучатися до розробки реабілітаційних онлайн-програм, їх методичного забезпечення, сайтів та сервісів сучасних інформаційних технологій.
\end{abstract}

Ключові слова: реабілітація, інформаційно-комунікаційні технології, телереабілітація, телемедицина, травми.

\section{Вступ}

32020 р. світ перебуває у стані поширення коронавірусної інфекції, що зумовило значні зміни у функціонуванні систем охорони здоров'я усіх країн та України зокрема. Відповідно, разом із наданням медичної допомоги при різних нозологіях значно постраждали умови реалізації безперервного відновного лікування пацієнтів із травмами. Пацієнти, які потребують реабілітації, втратили важливі складові її ефективного забезпечення: регулярний контроль за реакцією на дію реабілітаційних заходів та доцільністю їх використання і, найголовніше, можливість корекції для досягнення ефективності реабілітаційного процесу.

Саме в такій ситуації може бути використана віртуальна допомога, яка особливо важлива в період пандемії COVID-19, але В той самий час $\epsilon$ цінним додатковим клінічним інструментом поза періодом пандемії [1]. Для цього можуть бути використані сучасні інформаційно-комунікаційні канали, серед яких слід надавати перевагу засобам з можливістю аудіо- та відеозв'язку: програми широкого використання (Viber, Skype, Zoom, Instagram та ін.) чи спеціалізовані телемедичні/телереабілітаційні програми. Вони дозволять забезпечити зв'язок фахівця з відновного лікування/реабілітації з пацієнтом. Якщо розглядати телемедицину в цілому, то головною ії метою визначено поліпшення здоров'я населення шляхом забезпечення рівного доступу до медичних послуг належної якості, в тому числі коли відстань $\epsilon$ критичним чинником її надання [2]. Відповідно до Закону України від 03.12.2020 р. № 1053-ІХ «Про реабілітацію у сфері охорони здоров'я» телереабілітація - здійснення реабілітаційних заходів із використанням засобів дистанційного зв'язку.

Ортопедична реабілітація має першорядне значення після травми або операції з відновлення порушеної функції. Успішна терапія потребує відповідної комбінації та прогресування вправ для поліпшення мобілізації суглобів та зміцнення м'язів для від- новлення фізичної функції. Реабілітаційні заходи повинні розпочинатися якнайшвидше і обов'язково підтримуватися у домашніх умовах. Технологічний прогрес відкриває нові перспективи у сучасній реабілітації. Віртуальна реальність, доповнена реальність, гейміфікація та телереабілітація роблять привабливою реабілітацію пацієнтів із ураженнями опорно-рухового апараTy $[3,4]$.

Ці технології скорочують час госпіталізації та витрати на лікування і збільшують кількість пацієнтів, які можуть одночасно лікуватися [5]. Інший позитивний аспект цих реабілітаційних режимів - пряма і безперервна взаємодія між пацієнтом та медичним працівником, що підвищує дотримування лікування [6]. Результати досліджень показали, що дистанційна віртуальна реабілітація підвищує мотивацію пацієнта, покращуючи прихильність до терапії [7].

Враховуючи ситуацію, спричинену пандемією COVID-19, та введення карантинних заходів в усьому світі, питання віртуальної допомоги та телемедицини стало досить актуальним як у сфері надання реабілітаційних послуг, так і в медицині в цілому. Але чи готові фахівці з реабілітації до впровадження та реалізації цих заходів?

Мета: визначити готовність і потенційні можливості використання інформаційно-комунікаційних технологій фахівцями 3 реабілітації для забезпечення ефективної безперервної реабілітаційної допомоги пацієнтам із травмами у сучасних умовах.

\section{0б'єкт і методи дослідження}

Використано методи системного підходу і системного аналізу, соціологічний та статистичний методи. У дослідженні взяли участь 62 фахівці з реабілітації, з яких 25 (40,3\%) чоловіків та 37 (59,7\%) жінок. Фахівці, що дали згоду на участь в опитуванні, займаються фізичною реабілітацією і працюють у закладах охорони здоров'я (41,9\%), реабілітаційних закладах $(30,6 \%)$ чи $\epsilon$ приватними підприємцями (25,8\%). Опитування проводи- 
ли дистанційно за допомогою спеціально розроблених анкет, які надсилали респондентам в електронному вигляді. Анкета містила 25 питань, 3 яких 3 питання загального характеру (вік, стать, місце роботи) та 22 питання, зміст яких спрямований на готовність використання сучасних інформаційних технологій у процесі забезпечення безперервного процесу реабілітації та думку щодо можливості їх застосування на практиці. Визначали відсоткові значення відповідей із 95\% довірчим інтервалом.

Для підрахунку отриманих даних використані ліцензована програма «IBM SPSS Statistics», «Microsoft Excel» та «Google Sheets» (таблиці).

\section{Результати та їх обговорення}

Більшість опитаних фахівців із фізичної реабілітації $(91,9 \pm 6,8 \%)$ вказали на наявність у них вільного доступу до мережі Інтернет через засоби комунікації (смартфон, планшет, телефон та ін.) на робочому місці і лише $8,1 \pm 6,8 \%$ зазначили про відсутність такого. При цьому тільки $64,5 \pm 12,0 \%$ респондентів вважають доцільним та ефективним використання сучасних інформаційно-комунікаційних технологій та телемедицини в реабілітації, на відміну від $14,5 \pm 8,8 \%$, які так не вважають, та $21,0 \pm 10,2 \%$, які ще не визначилися.

Відповідно до Постанови Кабінету Міністрів України від 11.03.2020 р. № 211 «Про запобігання поширенню на території України гострої респіраторної хвороби COVID-19, спричиненої коронавірусом SARS-CoV-2», на всій території України з 12.03.2020 р. вперше установлений карантин, який рядом інших постанов Кабінету Міністрів України продовжений на території всієї країни та окремих її областей дотепер. Враховуючи динаміку епідемічної ситуації, можна прогнозувати, що карантинні заходи триватимуть ще невизначений час. Саме тому нами ініційовано також опитування учасників дослідження щодо доцільності застосування сучасних інформаційних технологій та телемедицини для забезпечення безперервної реабілітації в умовах карантину та обмеження доступу пацієнтів до закладів охорони здоров'я.

Отже, про доцільність застосування сучасних інформаційних технологій та телемедицини для забезпечення безперервної реабілітації в умовах карантину та обмеження доступу пацієнтів до закладів охорони здоров'я вказали $79,0 \pm 10,2 \%$ опитаних фахівців. При аналізі відповідей учасників дослідження встановлено, що 48,4 $12,5 \%$ з них вже готові використовувати сучасні комунікаційні технології у проведенні реабілітації пацієнтів під час карантину, 30,6士11,5\% зазначили, що готові,

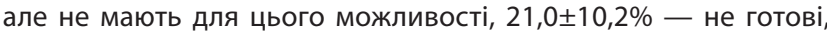
оскільки вважають використання сучасних інформаційних технологій для забезпечення реабілітаційного процесу неефективним (рис. 1).

Рисунок 1 Розподіл відповідей респондентів (фахівців) щодо готовності використання сучасних інформаційних технологій у реабілітації

60

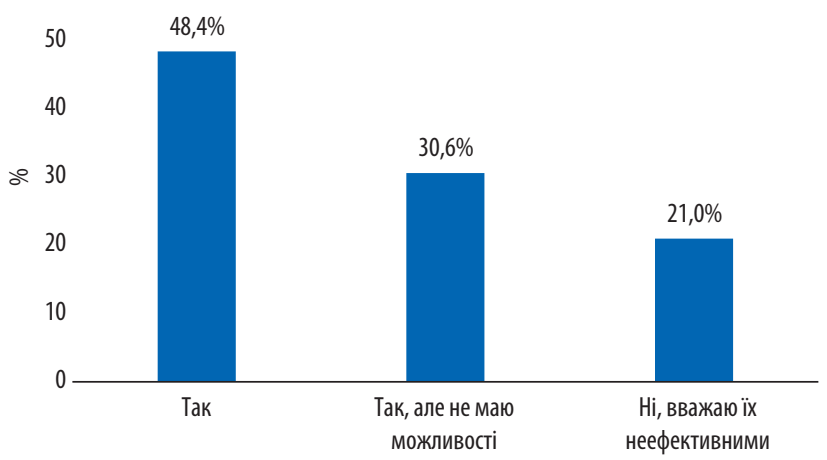

Серед пріоритетних для використання засобів телемедицини та телереабілітації, на думку респондентів, - мобіль- ні системи телемедицини (66,1 $11,9 \%)$, далі в порядку змен-

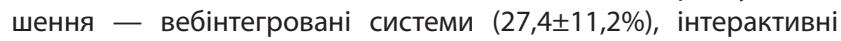
(роботизовані) $(25,8 \pm 11,0 \%)$, сенсорні системи телемедицини $(22,6 \pm 10,5 \%)$, синхронні $(21,0 \pm 10,2 \%)$ та біотелеметричні засоби $(21,0 \pm 10,2 \%)$ (рис. 2).

Рисунок 2 Пріоритетні засоби телемедицини та телереабілітації, на думку фахівців із реабілітації

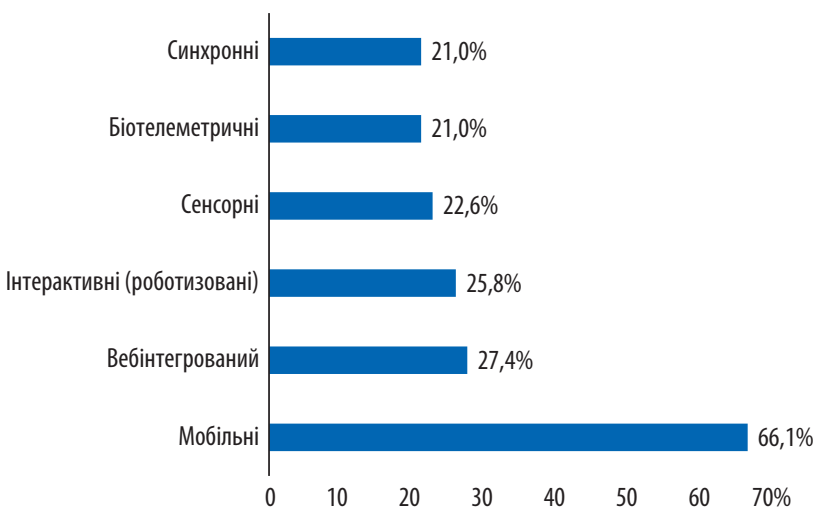

При подальшому аналізі встановлено, що у $54,8 \pm 12,5 \%$ опитаних вже був досвід застосування сучасних комунікаційних технологій та засобів телемедицини на практиці з пацієнтами, що свідчить про позитивні перспективи розвитку застосування таких технологій фахівцями з фізичної реабілітації.

При опрацюванні даних літератури з'ясовано, що в Україні недостатнє науково обгрунтоване методичне забезпечення використання засобів телемедицини та сучасних інформаційнокомунікаційних технологій у сфері реабілітаційної медицини. Це спонукало нас до визначення готовності фахівців із фізичної реабілітації долучитися до розробки реабілітаційних онлайнпрограм, їх методичного забезпечення, сайтів та сервісів сучасних інформаційних технологій для забезпечення безперервної реабілітації пацієнтів. Отже, 45,2 $12,5 \%$ респондентів відповіли,

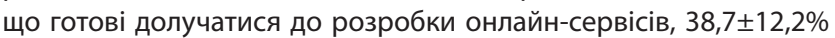
не визначилися, $16,1 \pm 9,2 \%$ вказали, що не готові брати участь у розробці таких програм.

Також нами ініційовано опитування щодо визначення потенційної можливості застосування респондентами сучасних засобів телемедицини та комунікації для забезпечення безперервності реабілітаційного процесу. На запитання «Чи були 6 Ви зацікавлені в тому, щоб запропонувати пацієнтові дистанційне відновне лікування, якщо для цього є всі умови та можливості?» більшість

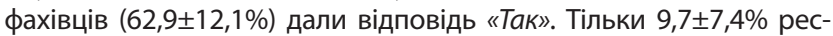
пондентів дали негативну відповідь і зазначили, що не зацікавлені у тому, щоб за своєю ініціативою запропонувати пацієнтові засоби дистанційної реабілітаційної допомоги. Інші учасники не визначилися.

Після аналізу попередніх результатів стало важливим визначення пріоритетних сторін, на думку респондентів нашого дослідження, що мають виявляти основну ініціативу щодо застосування сучасних інформаційних реабілітаційних технологій, засобів телемедицини та телереабілітації. Визначено, що $58,1 \pm 12,4 \%$ опитаних фахівців вважають, що ініціативу мають виявляти всі сторони. Заклади охорони здоров'я в цій ролі

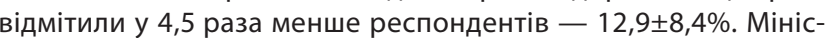
терство охорони здоров'я України як ініціатора впровадження вказаних засобів назвали ще менше фахівців - 11,3土7,9\%. Така сама частка учасників дослідження $(11,3 \pm 7,9 \%)$ зазначили, що основна ініціатива має йти від лікаря чи фізичного терапевта.

При подальшому опрацюванні результатів опитування визначали ставлення респондентів до перспективи розвитку впровадження і застосування дистанційного відновного лікування в Україні. Можна вважати позитивним, що більшість опитаних $(62,9 \pm 12,1 \%)$ вказали, що бачать таку перспективу за умови, що над її розвитком потрібно ще багато працювати. Тільки 
$17,7 \pm 9,6 \%$ респондентів зазначили про наявність значної перспективи, яка буде реалізована найближчим часом. Слід звернути увагу, що 12,9 7,9\% опитаних вважають, що перспектива впровадження і застосування дистанційної реабілітаційної допомоги в Україні відсутня саме через незацікавленість лікарів та фахівців (рис. 3).

Рисунок 3 Перспективи застосування сучасних інформаційних технологій у реабілітації в Україні, на думку респондентів

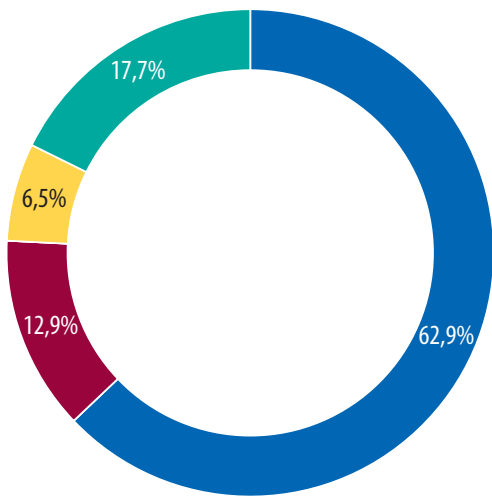

- Перспектива $\epsilon$ але потрібно ще багато над цим працювати

- Перспективи немає через незацікавленість лікарів

- Перспективи немає через незацікавленість пацієнтів

- Перспектива велика і буде успішною найближчим часом

Безперервність проведення реабілітації - один з основних факторів, що забезпечують її ефективність та позитивний вплив на стан пацієнта. Тому важливим $\epsilon$ питання, на якому 3 етапів реабілітаційного процесу можливе застосування сучасних інформаційних технологій, на думку фахівців із фізичної реабілітації. Більшість опитаних $(62,9 \pm 12,1 \%)$ надають перевагу можливості застосування сучасних інформаційних технологій протягом всього процесу реабілітації. Про можливе застосування онлайн-реабілітації лише на кінцевому етапі лікування для оцінки результатів зазначили $33,9 \pm 11,9 \%$ респондентів, а застосування на початковому етапі процесу реабілітації вважають доцільним лише $12,9 \pm 7,9 \%$ учасників дослідження. Також $14,5 \pm 8,8 \%$ опитаних вказали, що сучасні інформаційні технології не можна використати на жодному з етапів процесу реабілітації, оскільки, на їх думку, таке застосування неефективне.

Важливим стало визначення, хто ж повинен нести відповідальність за тих пацієнтів, які самостійно неспроможні повною мірою користуватися сучасними засобами онлайн-зв'язку, що, у свою чергу, може і буде впливати на ефективність відновного лікування. Більшість опитаних фахівців $(56,5 \pm 12,4 \%)$ зазначили про відповідальність за вміння пацієнта користуватися засобами комунікації з боку фахівця, який призначає та контролює

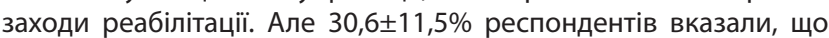
користуватися вказаними засобами пацієнтів повинні навчити їх родичі та близькі, або ж самі пацієнти повинні вміти їх використовувати. Але $41,9 \pm 12,4 \%$ учасників дослідження зазначили, що для навчання пацієнтів повинні бути спеціально підготовлені фахівці (рис. 4).

Рисунок 4 Розподіл відповідей респондентів щодо відповідальності за вміння пацієнтів користуватися засобами комунікації

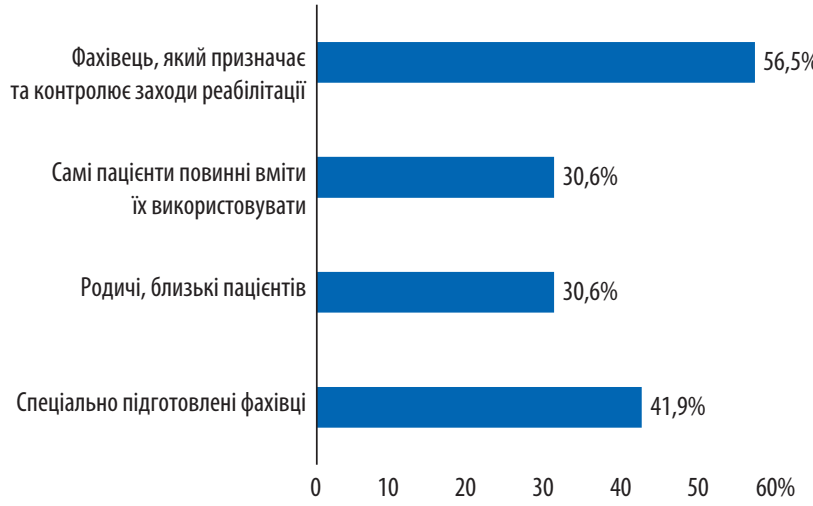

Також проаналізовано можливі ризики при використанні сучасних інформаційно-комунікаційних технологій та засобів телемедицини для забезпечення безперервного процесу реабілітації та досягнення максимальної ефективності. Для 53,2ะ12,5\% опитаних фахівців найвищим ризиком $\epsilon$ неможливість контро-

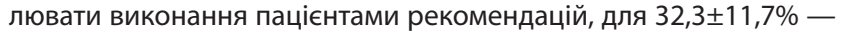
погіршення стану пацієнтів у процесі виконання програми реабілітації вдома. Зазначимо, що 46,8 $12,5 \%$ респондентів вказали, що недостатня мотивація пацієнтів до виконання завдань $\epsilon$ також ризиком проведення реабілітації пацієнтів із травмами з використанням онлайн-технологій.

Завершальним етапом став аналіз відповідей фахівців щодо перешкод на шляху до впровадження заходів телереабілітації пацієнтів. Найбільшими перешкодами респонденти вважають відсутність умов у пацієнтів для виконання програми реабілітації вдома $(51,6 \pm 12,5 \%)$, низьку прихильність пацієнтів $(48,4 \pm 12,5 \%)$ та відсутність у них доступу до мережі Інтернет $(45,2 \pm 12,5 \%)$. В той самий час досить велика частка $(32,3 \pm 11,7 \%)$ вказали, що перешкодою може стати відсутність мотивації у фахівців із реабілітації.

\section{Висновки}

Визначено основні компоненти готовності фахівців із реабілітації до використання інформаційно-комунікаційних каналів:

1. Встановлено високий рівень $(79,0 \%)$ готовності до використання сучасних інформаційно-комунікаційних технологій у реабілітації пацієнтів із травмами у своїй практиці $(48,4 \%-$ повна готовність, 30,6\% - готовність 3 відсутністю можливості).

2. Визначено середній рівень $(45,2 \%)$ готовності долучатися до розробки реабілітаційних онлайн-програм, їх методичного забезпечення, сайтів та сервісів сучасних інформаційних технологій для забезпечення безперервної реабілітації паці$\epsilon$ нтів.

Загалом використання сучасних інформаційно-комунікаційних каналів в реабілітації пацієнтів після травм $\epsilon$ одним 3 перспективних шляхів вдосконалення системи охорони здоров'я та реабілітації зокрема, що допоможе в умовах обмеженого фінансування та карантину досягти підвищення ефективності відновного лікування, його медичного моніторингу, підвищення якості, зниження ризику виникнення ускладнень після травм.

Конфлікт інтересів: відсутній.

Conflict of interests: the authors declare no conflict of interests.

\section{Список використаної літератури/References:}

1. McIntyre M., Robinson L.R., Mayo A. (2020) Practical Considerations for Implementing Virtual Care in Physical Medicine and Rehabilitation: For the Pandemic and Beyond. Am. J. Phys. Med. Rehabil., 99(6): 464-467. D0I:10.1097/PHM.0000000000001453

2. Voronenko Yu.V., Orabina T.M., Moiseenko R.I. et al. (2019) Guidelines for the diagnosis and treatment of certain diseases in the provision of telemedicine services (for general practitioners — family medicine). P.L. Shupyk NMAPE, Kyiv, 104 p. (In Ukr.).

3. Negrillo-Cárdenas J., Jiménez-Pérez J.R., Feito, F.R. (2020) The role of virtual and augmented reality in orthopedic trauma surgery: From diagnosis to rehabilitation. Computer methods and programs in biomedicine, 191: 105407. D01:10.1016/j.cmpb.2020.105407

4. Berton A., Longo U.G., Candela V. et al. (2020) Virtual reality, augmented reality, gamification, and telerehabilitation: Psychological impact on orthopedic patients' rehabilitation. J. Clin. Med., 9(8): 2567. D0l:10.3390/jcm9082567

5. Doiron-Cadrin P., Kairy D., Vendittoli P. A. et al. (2016) Effects of a tele-prehabilitation program or an in-person prehabilitation program in surgical candidates awaiting total hip or knee arthroplasty: Protocol of a pilot single blind randomized controlled trial. Contemporary clinical trials communications, 4: 192-198. D01:10.1016/j.conctc.2016.10.001

6. Kuether J., Moore A., Kahan J. et al. (2019) Telerehabilitation for Total Hip and Knee Arthroplasty Patients: A Pilot Series with High Patient Satisfaction. HSS J., 15(3): 221-225. D0I:10.1007/s11420-019-09715-w

7. Then J.W., Shivdas S., Tunku S.T.A.Y. et al. (2020) Gamification in rehabilitation of metacarpal fracture using cost-effective end-user device: A randomized controlled trial. J. Hand. Ther., 33(2): 235-242. doi: 10.1016/j.jht.2020.03.029 


\section{Readiness of rehabilitation specialists} to use modern information and communication technologies to provide continuous rehabilitation to patients with injuries

\section{V.V. Brych, N.Y. Khodakovska}

Uzhhorod National University, Uzhhorod, Ukraine

Abstract. The aim is to investigate and determine the readiness and potential use of information and communication technologies by rehabilitation specialists to provide effective continuous rehabilitation to patients with injuries in current conditions. Object and methods of research. System approach and system analysis, sociological and statistical research methods were used. The study involved 62 rehabilitation specialists, the survey was conducted remotely using specially designed questionnaires of 25 questions. Results. $64.5 \pm 12.0 \%$ of respondents consider it expedient and effective to use modern information and communication technologies and telemedicine in rehabilitation. $48.4 \pm 12.5 \%$ of the surveyed specialists are ready to use modern communication technologies in the rehabilitation of their patients during quarantine, $30.6 \pm 11.5 \%$ of specialists indicated that they are ready, but do not have the opportunity to do so, and $21.0 \pm 10.2 \%$ of respondents indicated that they were not ready because they considered them ineffective. $45.2 \pm 12.5 \%$ of respondents are ready to join the development of online rehabilitation programs, their methodological support, sites and services of modern information technologies to ensure continuous rehabilitation of patients. The main obstacles and risks of telerehabilitation in the opinion of the interviewed rehabilitation specialists were identified. Conclusions. A high level (79.0\%) of readiness of rehabilitation specialists to use modern information and communication technologies in the rehabilitation of patients with injuries in their practice and an average level (45.2\%) of readiness to participate in the development of online rehabilitation programs, their methodological support, sites and services of modern information technologies.

Key words: rehabilitation, information and communication technologies, telerehabilitation, telemedicine, injuries.
Information about the authors:

Brych Valeriya V. - Candidate of Medical Sciences, Associate Professor at the Department of Health Sciences of the Uzhhorod National University, Uzhhorod, Ukraine. ORCID ID: 0000-0003-3741-6002

Khodakovska Nadiia Y. - Master's Student in 229 «Public health» of the Uzhhorod National University, Uzhhorod, Ukraine.

Address for correspondence:

Valeriya Brych

88000, Uzhhorod, Mytna str., 29

E-mail: valeria.bruch@uzhnu.edu.ua 